The International Journal of Engineering and Science (IJES)

|| Volume || 6 || Issue || 6 || Pages || PP 09-13 || 2017 ||

ISSN (e): $2319-1813$ ISSN (p): $2319-1805$

\title{
Impact of Sewage Discharge on Coral Reefs
}

\author{
Nadia J. Alsabah \\ Higher Institute of Telecommunications and Navigation (HITN) - Navigation Department State of Kuwait
}

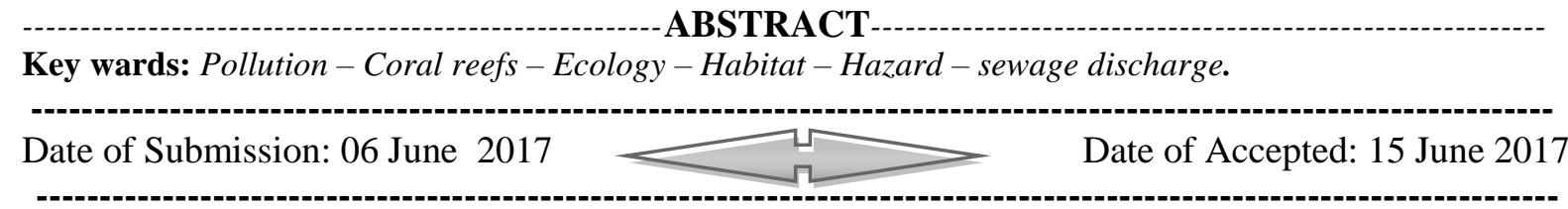

\section{INTRODUCTION}

The problem on the sewage pollution of coral reefs has been present for quite some time. In fact, the current regulations allow public treatment so that there can be a modification of the pollutant discharge. Coral reefs are seen as "distinctive habitats of limited distribution." It is critical that they are protected because of their importance to man. This paper looks at the ecological impact of the different discharges of coral reefs. There are three major components of sewage control and this includes eutrophication which is related to the high nutrient concentration which is released in the waste waters; the sedimentation of suspended solids and its toxic effects. (Ecological Impacts of Sewage Discharges on Coral Reef Communities). Different other factors are hazards to coral reefs such as climate change and overfishing, but pollution that arises from untreated sewage is a more serious danger to reefs. (Hausheer, 2015).

\section{RESULT AND DISSECTION}

\section{Challenging Stressors}

There are a lot of pressures from global climate to ocean change that add to the local scale stressors making it a real problem for coral reef managers. It is, therefore, important that one exercises an understanding of how these stressors converge for the successful conservation of reef. Coral reef vulnerability needs to be taken into consideration as well as the operational framework to enhance the resilience and management decisions on reducing these vulnerabilities. Authors Anthony and colleagues (2014) propose an Adaptive Resilience-Based management (ARBM) framework so there are guidelines on how and where resilience can be enhanced via management interventions. The key threats to coral reef resilience come from press-type stressors such as overfishing,pollution, sedimentation, acidification and overfishing. These are stressors affect processes on recovery while the pulsetype (acute) stressors increase the demand for resilience.

Coral reefs are important for servicing people and their needs, and this includes other benefits such as fisheries production, shoreline protection and livelihoods for ecotourism. Consultants think that these services are worth $\$ 31$ billion each year.(Hausheer, 2015). The influx of sewage is not beneficial both for people and for marine life. Untreated sewage can produce excess nutrients which can disrupt the battle between the coral and the seaweed for space and light. In that case, corals dominate, but the presence of excess nutrients can be more favorable for the seaweed (Hausheer, 2015).

\section{Ocean-Atmospheric Interface}

The coral reefs in the Australia's Great Barrier Reef are getting bleached. Scorching hot seasons have caused certain organisms to grow rapidly on the corals and cause their bleaching and death (Science, 2016). A result of a warmer ocean on climate is that temperatures may continue to rise. This is because a warmer ocean results in the decreased release of sulfur from the ocean into the atmosphere, which in turn reduces the amount of solar radiation reflected back into space, resulting in a warmer atmosphere (Fujita, 2013).

Climate change and global warming have had the impact of resulting in stronger and more destructive hurricanes and storms. With the glaciers melting, sea levels have risen as well. Hurricanes will derive more strength regarding wind speed and water content because they can feed off the warmer air above the oceans. It is projected that hurricanes will be 2-11\% more intense than in the previous century (Geophysical Fluid Dynamics Laboratory, 2015).

The impact rising sea levels and stronger hurricanes will have devastating consequences for coastal communities. There will be flooding, shoreline erosion, and water pollution. Homes along these coasts may have to be abandoned and their residents transferred inland if sea levels continue to rise. These homes also bear the brunt of storms coming from the ocean or sea (EPA, 2016). 
The extent of sewage pollution is alarming, and it is evident that 96 percent of places that have coral reefs and people demonstrate a pollution problem (Hausheer, 2015). Most of the sewage pollute the ocean remain to be untreated discharge especially if it is a developing country. For instance, about 85 percent of wastewater that enters the sea in the Caribbean is not treated at all according to the United Nations Environmental Program. (Hausheer, 2015). Even in the United States, the infrastructure at present is poorly maintained that causes pollution to leak or overflow into the waterways during heavy rains (Hausheer, 2015).

The reefs that are close to people can suffer due to the changes in the environment such as poor water quality from the sources of pollution in the land. (How Pollution Affects Coral Reefs). These sources are the primary cause of coral reef degradation globally. For instance, in the Caribbean, the largest source of pollution comes from the activities on land. When people expand in their territories, the development changes the landscape which results in an increase of runoff from the land. This is not beneficial for the coral reefs because the runoff can carry large quantities of sewage outflows and petroleum products as well as high levels of nutrients from agricultural areas creating havoc in the reefs' health. The excess in nutrients can affect the quality of the water and thus result in decreased oxygen and increased nutrients in the water (eutrophication). An offshoot of this is that it will also lead to the increase in algal growth on the reefs, which critically degrades the ecosystem. The sediments that are deposited into these reefs can interfere with their ability to multiply and get the proper feeding. At the same time, the pesticides that are deposited into it can interfere with their growth, even increasing the pathogens into the ecosystems. An example of this is the Serratia marcescens which are associated with a coral disease known as white pox.(How Pollution Affects Coral Reefs).

\section{Nutrients Loading}

Pollution from sewage can lead to coral reef bleaching and other coral diseases (Large study sh0ows pollution impact). Coral bleaching just goes to show that there is stress on the reefs. A controlled study that lasted for three years yielded results that demonstrate how elevated levels of nitrogen and phosphorus in the Florida Keys from 2009 until 2012 doubled the amount of coral bleaching. It also showed how these reefs recovered after the pollutants stopped. Rebecca Thurber, an assistant professor at the College of Science at the Oregon State University, revealed that bleaching of the reefs happened because of the sewage discharge and fertilizers that came from the urban and agricultural use.(Large study shows pollution impact). Scientists were shocked to discover that more than 80 percent of the corals have disappeared during the past decades. This was alarming because the reefs hosts thousands of fish species and various marine life and the devastation could be critical for man's ecological peace. However, until now, there are very few long-term experiments that have been done to prevent the impact of nutrient overloads. Experiments that introduced regular injections of nutrients at the study sites demonstrate that 1200 corals showed signs of coral disease and bleaching,

One of the diseases that were common at that time was the "dark spot syndrome" which was found on 50 percent of diseases of individual corals. After this result, the experiment also revealed that within one year after the nutrient injections stopped, the degree of the dark spot syndrome had decreased to the same level as those control study places where no nutrients were injected. The exact kind of nutrient overload is still vague, but it is evident that nutrients can add pathogens and make these pathogens grow and multiply in those reefs. This is toxic to the corals and will make them vulnerable to other kinds of pathogens. This situation will stress out the coral health, and concrete steps to address this are in order. Cleaning up the water seems to be the biggest challenge now that this has been identified as the cause of the coral reefs' destruction. The problem is still within control as long as the people responsible take concrete steps to remedy the problem.

At present, there are about 112 coral reef geographies, with 104 possessing sewage contamination problems. (Wear\&Vega-Thurber, 2015). Even if this is the reality now, conservationists are not attentive to the problem because they are dealing with large scale diffuse threat and the high costs that treatment will require. Sewage is a convergence of many other potentially toxic and distinct stressors which include inorganic nutrients, pathogens, suspended solids, heavy metals, sediments and other toxins. (Wear\& Vega-Thurber, 2015).

Different components render stress on coral reefs, and fresh water does a lot of damage as it is well documented that the influx of fresh water from storms can increase its mortality. Endocrine disruptors are chemicals that can destroy the hormone system of both humans and other living things. This includes the petrochemicals and synthetic estrogens that are linked to several human health problems as well (Hausheer, 2015). Heavy metals can also find its way on coral reefs, and these chemicals can result in a bleaching death as well as a decreased reproductive success on corals. These heavy metals can seep inside the corals and thus, increase the strength of the pathogens on the surface of the corals, making it very susceptible to infection. Sewage abounds in bacteria and fecal matter that can lead to contamination. This is the same with corals because it researchers found out that a bacterium which was linked to hospital-acquired infections in humans was the one causing the white pox disease in the Elkhorn corals. Unfortunately, when this broke out, there were about 70 percent of corals that were killed in the corals of Florida Keys. (Hausheer, 2015). 
Marine debris can severely affect the reefs in many areas. This can be in the form of pollutants made by man that is disposed of, discarded or abandoned which enters the coastal and ocean waters. Waste can also come directly from a ship and out to sea, rivers and storm drains. This can include debris, plastics, glass, metal, and even tires. (How Pollution Affects Coral Reefs). Abandoned fishing nets, often called "ghost nets" is called as such because they are able to catch fish even they have been abandoned.

\section{Case Histories}

Short-term studies have been the usual approach in investigating sewage pollution effects on the ecosystems of coral reefs. One of the sewage-stressed reef ecosystems that have been investigated is the Kaneohe Bay. There has been an increased in the proliferation of benthic algae as well as filter feeding invertebrates. Studies by Walker and Ormond (1982) confirm that this lead to chronic sewage pollution. Author Barnes (1973) claimed that there is evidence of a chemical stress, solids deposition, nutrient enrichment, as well as bacterial contamination on the coral reefs which experience low volumes of sewage effluent from the different hotels in Jamaica. Response identified sewage loading increase in benthic algae and filters feeding invertebrates like sponges, tunicates, bryozoans and decrease in the diversity and abundance of hermatypic corals. In Aqaba, Jordan, the sewage discharge as well as the deposition of sediments creates a significant impact in the place. Even if the importance of the sewage pollution was not immediately seen, the spatial effects of the sewage discharge were apparent. There was an increase in algal activity and a decrease in coral diversity. Walker and Ormond (1982) discovered that the death rate of the coral tissue near the outfall was 4 to 5 times the death rate observed in the control area.

\section{More efforts on preservation}

Even if the changes are seen as beneficial, there are still other sewage discharges on the reef biota that have not been carefully examined. Examples of this are the subtle variations in the ecology of the reef which is seen with the discharge of the toxic substances in sewage effluent. There are still healthy coral communities that exist in the turbid waters especially when the strong currents do not permit the buildup of sediments on coral surfaces (Marshal1 and Orr, 1931; Roy and Smith, 1971 as cited in Pastorok \& Bilyard). Still, the corals which are exposed to high turbidity or the rapid sedimentation are less diverse and less abundant than those present in clear waters (Roy and Smith, 1971; Loya, 1976a; Randall and Birkeland, 1978 as cited in Pastorok \& Bilyard). Since the penetration of light can limit the distribution of the coral depth, the increased turbidity levels can demonstrate an apparent shift of coral depth distributions toward shallower waters. Still, its relation to the light levels is still complicated and simplifying the relationship to turbidity is not seen yet. When there is an accumulation of sediment on the hard substrates, the larval settlement is inhibited, and there is no development (Edmondson, 1928; Maragos, 1972; Dodge and Vaisnys, 1977 as cited in Pastorok \& Bilyard). Nevertheless, despite this information, the present information on anthropogenic impacts are limited. There are biological changes that were seen near the outfall and these point to the discharge. This includes the abundance of fishes, increased diversity as well as the increased abundance of filter feeding bryozoans and changes in the abundances of small molluscs and important species. The short term studies which were done within a year after initiation of the small sewage discharges flow less than 1.9 X $104 \mathrm{~m} 3 \mathrm{~d}-1$ revealing little or no damage to the coral reefs.(Tsuda et al., 1975 as cited in Pastorok \& Bilyard). This just goes to show that even if the algal populations increase rapidly in response to the sewage enrichment, the impact on the community level of corals can take more than a year to develop after the discharge has begun.

\section{Kaneohe Bay, Hawaii}

Meanwhile, the effects of the sewage enrichment on the coral reef communities in Kaneohe Bay and their initial recovery after the diversion of wastewaters are well documented (Maragos and Chave, 1973; Banner, 1974; Laws and Redalje, 1979, 1982; Smith et al., 1981as cited in Pastorok \& Bilyard). There were major sewage inputs for 30 years and the sewage discharge rates had risen from 5.7 X 103 to 3.2 X 104 m3 d-' between 1950 and 1977, with most of the wastewaters receiving secondary treatment after 1963. The wastewaters from the Kailua-Kaneohe and Marine Corps were diverted to an open ocean outfall off Mokapu Point. Because of the nutrient enrichment by sewage discharges into southern Kaneohe Bay, the phytoplankton biomass was enhanced (Laws and Redalje, 1979; Smith et al., 1981 as cited in Pastorok \& Bilyard).The water-quality variables, including dissolved oxygen and inorganic nitrogen, showed either little change with distance from the sewage outfalls or little response to sewage diversion. Inorganic nitrogen levels were insensitive to sewage loading because of rapid uptake in a nitrogen-limited system (Laws and Redalje, 1979, 1982; Smith et al., 1981as cited in Pastorok \& Bilyard). Results revealed that the survival time of transplanted corals was directly proportional to the distance from the sewage outfalls. 


\section{Sensitivity of coral reefs}

It is important to note that coral reef ecosystems are very sensitive to different environmental disturbances. This is because corals possess narrow physiological tolerance ranges for environmental conditions (Johannes, 1975; Endean, 1976 as cited in Pastorak \& Bilyard). Any change in the physical and chemical conditions outside the given tolerance ranges can be detrimental to the growth of the corals and their survival (Johannes and Betzer, 1975; Endean, 1976; Pearson, 1981 as cited in Pastorok \& Bilyard). Another reason why they are sensitive to their environment is that the interaction that occurs between these key reef species such as the algae-coral competition and the plant-herbivore relations are highly vulnerable to stressors in pollution (Johannes and Betzer, 1975as cited in Pastorok \& Bilyard). When pollution destroys the hermatypic corals, there will be death in many reef species dependent on corals for their shelter, food, and refuge from predators.(Johannes, 1975 as cited in Pastorok \& Bilyard). The effects of the toxins can be enhanced when there is an increase in water temperature which likely happens in coral reef environments (Johannes and Betzer, 1975 as cited in Pastorok \& Bilyard). The effects of these high temperatures are faster biotic uptake, greater toxicity, and increased solubility.

\section{The need for adaptive resilience-based management of coral reefs}

Today, natural resource managers are challenged by cumulative stressors that make these ecosystems vulnerable including the societies that depend on their goods and services (Chapin et al., 2000 as cited in Pastorok \& Bilyard). The fact remains that coral reefs are vulnerable to climate change, global changes and ocean acidification as well as urban development, overfishing and pollution (Knowlton \& Jackson, 2008 as cited in Pastorok \& Bilyard). Managers of reefs are faced with the challenge to reduce pressures and exposures to stress and most importantly, support the resilience of these systems to these threats. They need to change their focus from just stress reduction to an expanding support of its resilience. This, in effect, is much more sustainable over the long haul. They need to lower sensitivity, enhance adaptive capacity and promote its recovery. (Marshall \& Shuttenberg, 2006 as cited in Pastorok \& Bilyard). Focusing on the resilience part will provide effective approaches that will help managers think of creative ways of combining efforts towards its goal. There will be a lot of challenges as climate change, and ocean acidification are already at the forefront of its challenges. These are expected to be real problems that would need concrete steps by managers of reefs. Adaptive resiliencebased management (ARBM) has been developed from the studies of ecological systems and social systems (Anderies et al., 2006 as cited in Pastorok \& Bilyard). Even if adaptive systems has been part of the practical implementation of resilience, there is still need to help conservation practitioners to identify viable intervention options as well as make decisions to reduce the vulnerability of these reefs under complex scenarios. ARBM efforts can only be successful if there is an integration of fundamental principles in ecosystem vulnerability. These concepts in the context of managing social-ecological systems have the ability to cope with the extrinsic pressures which include those beyond the control of coral reed managers.

However, there are limits to an ecosystems' resilience and managers are able to take note of this as they employ measures to support the environment of the reefs. It requires a set of innovative management alternatives that are able to tackle stressors and at the same time enhance the resilience of the ecosystems.

\section{CONCLUSION}

Understanding how these stressors work in affecting the vulnerability of the coral reefs is critical to its successful conservation at present and in the future. There must be a strategic management to increase its resilience. Conservationists need to come up with an operational framework to identify management levers that will enhance its resilience as well as support management decisions towards its successful operation. The press type kind of stressors such as pollution and ocean warming are key threats to coral reef resilience because it affects processes that underpin the resistance and recovery efforts. Meanwhile, pulse type efforts like bleaching and storms increase its demand for resilience.

Today, with many nations and communities practicing ecological programs, one could say that man's view of nature is changing. This is that humans are an integral part of creation and nature and the environment, thereby leading to a new concept of environmental ethics. Hopefully, modern and pre-modern men's view of the environment will have reconciled fully by the end of the 21 st century. Man's journey towards understanding his role on the planet and how he is an integral part of it will have come full circle, and that the knowledge that we are stewards and guardians of our planet will be translated into steps and plans that will be implemented by all people regardless of race or creed.

There needs to be a combined strategy of resilience support, knowledge of reef ecosystem processes, the strategy of active risk reduction and an understanding of environmental and social drivers. The adaptive management of coral reefs will become increasingly difficult if these factors are not taken into consideration. It is a fact that sewage effluent is harmful to coral-reef communities. Their effects can be gleaned by the quantity and the quality of effluent as well as the hydrography of the receiving waters. 


\section{REFRENCES}

[1] Barnes, E. S. "Sewage pollution from tourist hotels in Jamaica.” Mar. Pollut. Bull. 4: 102-105, 1973.

[2] Byington, Cara. From Theory to Practice: Managing Coral Reefs for Resilience. 2014. Retrieved from: http://blog.nature.org/science/2014/10/16/theory-new-research-managing-coral-reefs-resilience/

[3] Fujita, R. "As Ocean Warms, the Impacts Multiply.” 2013 Retrieved from: http://www.livescience.com/40206-as-ocean-warmsimpacts-multiply.html

[4] Geophysical Fluid Dynamics Laboratory. “Global Warming and Hurricanes.” $2015 . \quad$ Retrieved from: https://www.gfdl.noaa.go/global-warming-and-hurricanes/

[5] Global Change Biology 2015. Retrieved from: http://onlinelibrary.wiley.com/doi/10.1111/gcb.12700/pdf

[6] Grigg, Richard. "Effects of sewage discharge, fishing pressure and habitat complexity on coral ecosystems and reef fishes in Hawaii." 1983. Retrieved from: http://www.int-res.com/articles/meps/103/m103p025.pdf

[7] Hausheer, Justine. "Sewage Pollution: A Significant Threat to Coral Reefs." $2015 . \quad$ Retrieved from: http://blog.nature.org/science/2015/06/08/sewage-pollution-great-threat-coral-reefs/

[8] How Pollution Affects Coral Reefs. Retrieved from: https://celebrating200years.noaa.gov/visions/coral/side.html

[9] Large study shows pollution impact on coral reefs and offers solutions. News and Research Communications. Retrieved from: http://oregonstate.edu/ua/ncs/archives/2013/nov/large-study-shows-pollution-impact-coral-reefs-\%E2\%8093-and-offers-solution

[10] Pastorok, Robert \& Bilyard, Gordon. "Effects of sewage pollution on coral-reef communities." Tetra Tech, Inc..Bellevue, Washington. Retrieved from: http://www.int-res.com/articles/meps/21/m021p175.pdf

[11] "Turning science into actions: What scientists can do to inform marine resource management" Marine Ecosystems and Management. 2017. Retrieved from: https://meam.openchannels.org/news/meam/turning-science-actions-what-scientists-can- doinform-marine-resource-management

[12] Walker, D. I., Ormond, R. F. G. "Coral death from sewage and phosphate pollution at Aqaba, Red Sea.” 1982. Mar. Pollut. Bull. 13: 21-25

[13] Wear, Stephanie. "Doubling Down on Coral Reefs." 2015. Retrieved from: http://blog.nature.org/science/2015/02/27/doublingdown-coral-reefs-science-conservation-steph-wear

[14] Wear, S.L. and R. Vega-Thurber. "Mitigation Is Key For Coral Reef Stewardship.” Reef Resilience. 2015. Retrieved from: http://www.reefresilience.org/article-summaries/sewage-pollution-mitigation-is-key- for-coral-reef-stewardship/\# 